\title{
PENGARUH VIDEO TERHADAP PERILAKU PERAWATAN IBU DENGAN BALITA PNEUMONIA DI PUSKESMAS PIYUNGAN KABUPATEN BANTUL
}

\author{
Yuliatil Adawiyah $^{1}$, Sri Warsini ${ }^{2}$, Lely Lusmilasari ${ }^{3}$ \\ ${ }^{1}$ Magister Keperawatan, Fakultas Kedokteran, Kesehatan Masyarakat dan Keperawatan \\ Universitas Gadjah Mada Yogyakarta, Indonesia \\ ${ }^{2}$ Departemen Keperawatan Jiwa dan Komunitas, Fakultas Kedokteran, Kesehatan Masyarakat dan \\ Keperawatan Universitas Gadjah Mada Yogyakarta, Indonesia \\ ${ }^{3}$ Departemen Keperawatan Anak dan Maternitas, Fakultas Kedokteran, Kesehatan Masyarakat dan \\ Keperawatan Universitas Gadjah Mada Yogyakarta, Indonesia \\ Email: yuliati.adawiyah@gmail.com
}

\begin{abstract}
Abstrak
Balita dengan pneumonia memerlukan perawatan yang tepat karena pneumonia merupakan salah satu penyebab kematian balita di Indonesia. Perilaku perawatan ibu yang tepat merupakan faktor keberhasilan dalam menurunkan angka kematian balita, sehingga perilaku perawatan ibu terhadap balita pneumonia ini menjadi sangat penting. Salah satu cara yang dapat dilakukan untuk memperbaiki perilaku ibu yaitu dengan memberikan edukasi kesehatan. Edukasi menggunakan video diharapkan lebih efektif untuk meningkatkan perilaku perawatan ibu dengan balita pneumonia.Tujuan penelitian adalah untuk mengetahui pengaruh edukasi menggunakan video dibandingkan dengan leaflet terhadap perilaku perawatan ibu pada balita pneumonia. Jenis penelitian ini adalah quasi experimental, dengan desain pretest posttest with control group design. Penelitian dilakukan di wilayah kerja Puskesmas Piyungan Kabupaten Bantul, 68 responden menggunakan consecutive sampling. Perilaku perawatan ibu diukur dengan kuesioner Perilaku Perawatan Ibu dengan Balita Pneumonia. Hasil penelitian menunjukkan bahwa perilaku perawatan ibu sebelum diberikan edukasi pada kelompok perlakuan dalam kategori baik (mean=112,68), dan perilaku perawatan ibu mengalami peningkatan setelah pemberian intervensi $($ mean $=119,65)$ dengan nilai $\mathrm{p}=0,016$. Perilaku perawatan ibu sebelum diberikan edukasi kelompok kontrol (diberikan leaflet) dalam kategori baik (mean=110,41), dan perilaku perawatan ibu mengalami peningkatan setelah pemberian intervensi (mean=113,62) dengan nilai $p=0,003$. Edukasi menggunakan video berpengaruh terhadap perilaku perawatan ibu dengan balita pneumonia $(\mathrm{p}=0,015 ; \mathrm{d}=0,603)$.

Kesimpulan: Edukasi menggunakan video lebih berpengaruh terhadap perilaku perawatan ibu dengan balita pneumonia dibandingkan leaflet.
\end{abstract}

Kata kunci: Balita; Edukasi; Pneumonia; Perilaku Perawatan; Video

\begin{abstract}
Background: Toddlers with pneumonia need proper care because pneumonia is one of the causes of toddler mortality in Indonesia. Appropriate mother care behavior is a success factor in reducing toddler mortality, so the behavior of mother care for toddler pneumonia is very important. One way that can be done to improve mother behavior is by providing health
\end{abstract}


education. Education using videos is expected to be more effective in improving the care behavior of mothers with toddlers with pneumonia. Research purposes: Knowing the effect of educational using video compared to leaflets on mother care behavior in toddler with pneumonia. Method: This type of research is quasi experimental, with a pretest posttest design with control group design. The study was conducted in the work area of Piyungan Community Health Center, Bantul Regency, 68 respondents used consecutive sampling. Mother care behavior was measured by the Mother and Toddler Pneumonia Care Behavior questionnaire. Results: Mother care behavior before being given education in the treatment group is in the good category (mean =112.68), and mother care behavior increased after the intervention (mean $=119.65)$ with a value of $p=0.016$. Mother care behavior before being given education in the control group (given leaflets) is in good category $($ mean $=110.41)$, and mother care behavior increased after the intervention $($ mean = 113.62) with a value of $p=0.003$. Educational use of videos affects the care behavior of mothers with toddlers pneumonia $(p=0.015 ; d=0.603)$. Conclusion: Education using videos is more influential on the care behavior of mothers with toddler pneumonia than leaflets.

Keywords: Toddlers, Education, Pneumonia, Behavior care, Videos

\section{Pendahuluan}

Pneumonia merupakan infeksi saluran pernafasan akut yang merupakan peradangan parenkim paru yang umumnya terjadi di masa kanak-kanak, lebih sering terjadi pada masa bayi dan anak usia dini dan dapat menyebabkan kematian (Hockenberry, 2015). Kemenkes (2017) menjelaskan bahwa angka cakupan penemuan pneumonia balita di Indonesia mengalami peningkatan menjadi $63,45 \%$ pada tahun 2015 dan $65,27 \%$ pada tahun 2016. Peningkatan cakupan penemuan pneumonia di Indonesia terjadi karena perubahan angka perkiraan kasus dan peningkatan dalam kelengkapan pelaporan dari 83,08\% pada tahun 2014 menjadi 91,91\% pada tahun 2015 dan 94,12\% pada tahun 2016. Provinsi Daerah Istimewa Yogyakarta (DIY) menempati urutan ke 11 dari 33 provinsi yang ada dalam persentase pneumonia pada anak di tahun 2013 (Riskesdas, 2013).

Anak yang menderita pneumonia khususnya balita memerlukan perawatan yang tepat karena pneumonia merupakan salah satu penyebab kematian balita di Indonesia (Maramis, 2013). Perilaku perawatan ibu yang tepat merupakan faktor keberhasilan dalam menurunkan angka kematian balita, sehingga perilaku perawatan ibu terhadap balita pneumonia ini menjadi sangat penting (Ismayani, 2017).

Perilaku perawatan ibu yang kurang baik akan menyebabkan peningkatan kekambuhan pada anak pneumonia (Alfaqinisa, 2015). Dampak lain bila ibu tidak memberikan perawatan yang baik pada balita pneumonia maka akan memperberat penyakitnya, sehingga saat dibawa ke rumah sakit keadaannya semakin memburuk (Sari et al., 2012). Maka perilaku perawatan ibu yang kurang baik ini secara tidak langsung dapat meningkatkan angka kematian balita.

Wea et al. (2015) menyebutkan bahwa salah satu cara yang dapat dilakukan untuk memperbaiki perilaku ibu yaitu dengan memberikan edukasi kesehatan. Menurut Notoadmodjo (2011) edukasi kesehatan merupakan penambahan pengetahuan dan kemampuan seseorang melalui teknik praktik belajar atau instruksi secara individu untuk meningkatkan kesadaran akan nilai kesehatan sehingga dengan sadar mau mengubah perilakunya menjadi perilaku sehat. Keberhasilan edukasi kesehatan tergantung kepada 
media yang digunakan. Media yang menarik akan memberikan keyakinan, sehingga perubahan kognitif, afeksi dan psikomotor dapat dipercepat.

Penggunaan media audiovisual dalam hal ini video dalam pemberian edukasi kesehatan dianggap lebih efektif karena menggunakan dua panca indera dalam menyerap informasi, sehingga dapat menyerap suatu materi sebanyak 50\%. Sementara jika menggunakan media lain penyerapan materi hanya berkisar 30\% dari yang dilihat, $20 \%$ dari yang didengar dan 10\% dari yang dibaca (De Porter (2000) cit Silalahi (2017)). Selain itu media audiovisual juga menawarkan penyuluhan yang lebih menarik dan tidak monoton, yang dapat menampilkan gerak, gambar dan suara (Hermaningsih \& Nargis (2009) cit Nurdin (2015)).

Video sebagai media edukasi kesehatan memiliki banyak keunggulan, yaitu pesan yang disampaikan mudah diingat, dapat diulang-ulang untuk menambah kejelasan, menarik karena berbentuk gambar bergerak, dan juga dapat dimodifikasi sesuai dengan kebutuhan (Dwiyogo, 2013). Hal inilah yang melatarbelakangi peneliti memilih video dibandingkan media yang lain untuk menyampaikan edukasi kesehatan. Tujuan penelitian ini adalah untuk mengetahui pengaruh edukasi menggunakan video dibandingkan dengan leaflet terhadap perilaku perawatan ibu pada balita pneumonia.

\section{Metode Penelitian}

Jenis penelitian ini adalah quasi experimental, dengan desain pretest posttest with control group design. Variabel bebas dalam penelitian ini adalah edukasi menggunakan video. Variabel terikat dalam penelitian ini adalah perilaku perawatan ibu dengan balita pneumonia. Penelitian ini dilakukan pada bulan April - Mei 2019. Desa Srimulyo sebagai kelompok perlakuan dan Desa Srimartani sebagai kelompok kontrol di wilayah Piyungan Bantul. Responden dalam penelitian ini adalah ibu dengan balita yang pernah menderita pneumonia di wilayah Piyungan Kabupaten Bantul. Dari perhitungan besar sampel maka didapatkan jumlah responden dalam penelitian ini sebanyak 68 orang. Kriteria inklusi pada penelitian ini adalah ibu yang memiliki anak usia 10 bulan -59 bulan yang pernah menderita pneumonia menurut data Puskesmas Piyungan Kabupaten Bantul tahun 2018; ibu sebagai pengasuh utama balita di rumah; ibu dapat membaca dan menulis; bersedia mengikuti penelitian dengan menandatangani lembar persetujuan.

Instrumen yang digunakan dalam penelitian merupakan kuesioner demografi yang memuat karakteristik responden, kuesioner Perilaku Perawatan Ibu dengan Balita Pneumonia untuk mengukur perilaku perawatan ibu dengan balita pneumonia. Kuesioner Perilaku Perawatan Ibu dengan Balita Pneumonia sebanyak 27 item pernyataan dengan menggunakan skala likert mulai dari 1-5. Semakin tinggi skor menunjukkan perilaku semakin baik. Peneliti melakukan uji coba kuesioner Perilaku Perawatan Ibu dengan Balita Pneumonia terlebih dahulu pada 30 ibu dengan balita pneumonia di Desa Sitimulyo Piyungan Kabupaten Bantul. Kuesioner dinyatakan valid untuk digunakan $(r>0,361)$ dengan hasil cronbach alpha $(0,83)$.

Penelitian ini telah mendapatkan persyaratan kelayakan etik dari Komisi Etik Fakultas Kedokteran, Kesehatan Masyarakat dan Keperawatan Universitas Gadjah Mada pada 28 Januari 2019 dengan nomor KE/FK/0114/EC/2019. Analisis univariat dilakukan untuk melihat gambaran distribusi frekuensi pada karakteristik responden. Variabel dengan jenis data numerik disajikan dalam bentuk mean dan Standart Deviasi (SD), 
sedangkan variabel dengan jenis data kategorik disajikan dalam bentuk frekuensi dan persentase menggunakan uji chi square dan uji fisher. Analisis bivariat yang digunakan adalah paired t-test untuk membandingkan hasil pretest dan posttest pada responden penelitian kelompok intervensi maupun kelompok kontrol; independent t-test untuk membandingkan hasil posttest responden penelitian pada kelompok intervensi dan kelompok kontrol; uji Anova dan independent t-test untuk mengetahui hubungan variabel luar (usia ibu, pendidikan ibu, pendapatan keluarga, sumber informasi, dan jumlah anak) dengan perilaku perawatan ibu. Analisis multivariate yang digunakan adalah uji regresi linier untuk mengetahui apakah variabel luar mempengaruhi edukasi menggunakan video terhadap perilaku perawatan ibu.

\section{Hasil Penelitian}

Tabel 1 menyajikan data karakteristik responden. Hasil uji statistik menunjukkan bahwa usia ibu, pekerjaan ibu, pendapatan keluarga, jumlah anak, jenis kelamin anak, dan status imunisasi anak pada kedua kelompok tidak berbeda secara signifikan (homogen) nilai $\mathrm{p}>0,05$. Sementara pendidikan ibu dan paparan informasi pada kedua kelompok memiliki perbedaan (tidak homogen) dengan nilai $\mathrm{p}<0,05$.

Tabel 1. Karakteristik Responden Penelitian di Kecamatan Piyungan Kabupaten Bantul Tahun $2019(n=68)$

\begin{tabular}{|c|c|c|c|c|c|}
\hline \multirow{3}{*}{ Karakteristik } & \multicolumn{5}{|c|}{ Kelompok } \\
\hline & \multicolumn{2}{|c|}{$\begin{array}{c}\text { Perlakuan } \\
\mathrm{n}=34\end{array}$} & \multicolumn{2}{|c|}{$\begin{array}{c}\text { Kontrol } \\
\mathrm{n}=34\end{array}$} & \multirow[t]{2}{*}{$p$ Value } \\
\hline & (f) & $(\%)$ & (f) & $(\%)$ & \\
\hline \multicolumn{6}{|l|}{ Usia } \\
\hline $18-25$ th & 6 & 17,6 & 3 & 8,8 & \multirow{3}{*}{0,385} \\
\hline $26-35$ th & 14 & 41,2 & 19 & 55,9 & \\
\hline$\geq 36$ th & 14 & 41,2 & 12 & 35,3 & \\
\hline \multicolumn{6}{|l|}{ Pendidikan } \\
\hline Dasar & 8 & 23,5 & 18 & 52,9 & \multirow{3}{*}{$0,017 *$} \\
\hline Menengah & 23 & 67,6 & 16 & 47,1 & \\
\hline Tinggi & 3 & 8,8 & 0 & 0,0 & \\
\hline \multicolumn{6}{|l|}{ Pekerjaan } \\
\hline Bekerja & 6 & 17,6 & 1 & 2,9 & \multirow[t]{2}{*}{0,105} \\
\hline Tidak Bekerja & 28 & 82,4 & 33 & 97,1 & \\
\hline \multicolumn{6}{|l|}{ Pendapatan } \\
\hline >Rp. 1.527 .150 & 9 & 26,5 & 6 & 17,6 & \multirow[t]{3}{*}{0,609} \\
\hline Rp. 1.527 .150 & 10 & 29,4 & 13 & 38,2 & \\
\hline < Rp. 1.527.150 & 15 & 44,1 & 15 & 44,1 & \\
\hline \multicolumn{6}{|c|}{ Paparan informasi tentang perilaku perawatan pneumonia } \\
\hline Belum Pernah & 17 & 50 & 28 & 82,4 & \multirow[t]{2}{*}{$0,005^{*}$} \\
\hline Sudah Pernah & 17 & 50 & 6 & 17,6 & \\
\hline \multicolumn{6}{|c|}{ Sumber informasi (bagi yang sdh terpapar) } \\
\hline - TV & 3 & 17,6 & 2 & 33,3 & 0,265 \\
\hline
\end{tabular}




\begin{tabular}{|c|c|c|c|c|c|}
\hline \multirow[b]{2}{*}{ Karakteristik } & \multicolumn{5}{|c|}{ Kelompok } \\
\hline & \multicolumn{2}{|c|}{$\begin{array}{c}\text { Perlakuan } \\
\mathrm{n}=34\end{array}$} & \multicolumn{2}{|c|}{$\begin{array}{c}\text { Kontrol } \\
\mathrm{n}=34\end{array}$} & \multirow[t]{2}{*}{$p$ Value } \\
\hline - Internet & 5 & 29,4 & 1 & 16,7 & \\
\hline - Majalah & 0 & 0 & 1 & 16,7 & \\
\hline - Orang lain & 9 & 52,9 & 2 & 33,3 & \\
\hline \multicolumn{6}{|l|}{ Jumlah anak } \\
\hline 1 anak & 13 & 38,2 & 5 & 14,7 & 0,053 \\
\hline$>1$ anak & 21 & 61,8 & 29 & 85,3 & \\
\hline \multicolumn{6}{|l|}{ Jenis Kelamin anak } \\
\hline Laki-laki & 13 & 38,2 & 17 & 50 & 0,329 \\
\hline Perempuan & 21 & 61,8 & 17 & 50 & \\
\hline \multicolumn{6}{|l|}{ Imunisasi anak } \\
\hline Lengkap & 34 & 100 & 33 & 97,1 & 1,000 \\
\hline Tidak lengkap & 0 & 0 & 1 & 2,9 & \\
\hline
\end{tabular}

Keterangan: n: sampel; f: frekuensi; \%: persentase; $p=$ signifikansi; $(*)=p<0,05$, dianalisis menggunakan chi square dan fisher exact test

Hasil analisis tabel 2 menunjukkan bahwa perilaku perawatan ibu sebelum dan setelah intervensi pada kelompok perlakuan terdapat perbedaan secara signifikan dari pre test ke post test I dan dari post test I ke post test II ( $\mathrm{p}<0,05)$. Sementara perilaku perawatan ibu sebelum dan setelah intervensi pada kelompok kontrol terdapat perbedaan secara signifikan dari pre test ke post test $\mathrm{I}(\mathrm{p}<0,05)$. Sementara hasil analisis dari post test I ke post test II tidak terdapat perbedaan yang signifikan ( $\mathrm{p}>0,05)$.

Tabel 2. Perilaku Perawatan Ibu Sebelum dan Setelah Intervensi di Wilayah Piyungan Kabupaten Bantul $(n=68)$

\begin{tabular}{|c|c|c|}
\hline Kelompok & Mean \pm SD & $P$ \\
\hline \multicolumn{3}{|l|}{ Perlakuan } \\
\hline Pre test & $112,68 \pm 9,40$ & \\
\hline Post test $\mathrm{I}$ & $117,32 \pm 7,67$ & $<0,001 *$ \\
\hline Post test I & $117,32 \pm 7,67$ & \\
\hline Post test II & $119,65 \pm 8,67$ & $0,016^{*}$ \\
\hline \multicolumn{3}{|l|}{ Kontrol } \\
\hline Pre test & $110,41 \pm 11,34$ & \\
\hline Post test $\mathrm{I}$ & $113,62 \pm 11,25$ & $0,003^{*}$ \\
\hline Post test $\mathrm{I}$ & $113,62 \pm 11,25$ & \\
\hline Post test II & $113,62 \pm 11,25$ & 1,000 \\
\hline
\end{tabular}

Hasil analisis bivariat antara variabel bebas dan variabel terikat ditunjukkan pada Tabel 3. Hasil analis menunjukkan bahwa terdapat perbedaan signifikan $(p>0,05)$ antara perilaku ibu pada kelompok perlakuan dan kelompok kontrol. Nilai cohen $(d)$ perilaku $d=0,603$ berarti secara klinis memiliki efek besar.

Tabel 3. Perbedaan Pengaruh Edukasi Terhadap Perilaku Perawatan Ibu dengan Balita Pneumonia di Wilayah Kerja Puskesmas Piyungan Kecamatan Piyungan Kabupaten Bantul ( $n=68)$

\begin{tabular}{cccc}
\hline \multicolumn{2}{c}{ Kelompok } & & \\
\hline $\begin{array}{c}\text { Perlakuan } \\
(\mathrm{n}=34)\end{array}$ & $\begin{array}{c}\text { Kontrol } \\
(\mathrm{n}=34)\end{array}$ & $p$ & $D$ \\
\hline Mean (SD) & Mean (SD) & & \\
\hline
\end{tabular}


Hasil uji statistik di tabel 4 menunjukkan bahwa dari keempat variabel luar yaitu usia, pendidikan, pendapatan, dan paparan informasi hanya ada 1 variabel yang berhubungan yaitu paparan informasi. Disimpulkan bahwa ada hubungan antara paparan informasi tentang perilaku perawatan pneumonia dengan perilaku ibu $(p<0,05)$.

Tabel 4. Hubungan Variabel Luar dengan Perilaku Ibu Pada Kelompok Perlakuan Setelah Diberikan Edukasi $(\mathrm{n}=34)$

\begin{tabular}{lllll}
\hline Karakteristik & Kategori & Mean & SD & $P$ \\
& & & \\
\hline \multirow{3}{*}{ Usia ibu } & $18-25$ tahun & 1,22 & 5,78 & $0,144^{\mathrm{a}}$ \\
& $26-35$ tahun & 5,36 & 6,74 & \\
\hline \multirow{4}{*}{ Pendidikan ibu } & $>35$ tahun & 6,08 & 6,08 & \\
& Dasar & 3,31 & 5,14 & $0,082^{\mathrm{a}}$ \\
& Menengah & 5,82 & 6,99 & \\
Pendapatan & Tinggi & 11,00 & 6,24 & \\
& $>$ Rp. 1.527.150 & 4,13 & 7,65 & $0,812^{\mathrm{a}}$ \\
& Rp. 1.527.150 & 5,26 & 6,59 & \\
Paparan informasi tentang perilaku & <Rp. 1.527.150 & 5,43 & 5,91 & \\
perawatan pneumonia & Selum & 6,09 & 7,08 & $0,042^{\mathrm{b}^{*}}$ \\
& & 3,13 & 4,60 & \\
\hline
\end{tabular}

Keterangan: n: sampel; $p$ : signifikansi; dianalisis menggunakan $\mathrm{uji}^{\mathrm{a}}=$ Anova dan $\mathrm{uji}^{\mathrm{b}}=$ Independent T-test, $(*)=p<0,05$

Analisis multivariat ditunjukkan pada tabel 5. Hasil analisis menunjukkan bahwa pada model pertama terdapat 4 variabel, yaitu video, usia ibu, pendidikan ibu, dan informasi. Pada model kedua terdapat 3 variabel, yaitu video, pendidikan ibu, dan informasi, sedangkan variabel usia ibu hilang. Pada model ketiga tersisa 2 variabel yaitu video dan informasi, sedangkan variabel pendidikan ibu hilang.

Tabel 5. Analisis Multivariat Perilaku Ibu Pada Kelompok Perlakuan dan Kelompok Kontrol (n = 68)

\begin{tabular}{llll}
\hline Variabel & \multicolumn{3}{c}{ Perilaku } \\
\cline { 2 - 4 } & Koefisien Regresi & $p$ Value & CI 95\% \\
\hline Model I & 4,213 & $0,010^{*}$ & $1,051-7,374$ \\
Video & 1,818 & 0,100 & $-0,359-3,995$ \\
Usia ibu & 2,530 & 0,067 & $-0,187-5,247$ \\
Pendidikan ibu & $-4,209$ & $0,011^{*}$ & $-7,428-(-0,990)$ \\
Informasi & 0,322 & 0,942 & $-8,518-9,161$ \\
Konstanta & & 0,214 & \\
$\mathrm{R}^{2}$ & & & \\
\hline Model II & 4,556 & $0,006^{*}$ & $1,379-7,733$ \\
Video & 2,028 & 0,136 & $-0,658-4,713$ \\
Pendidikan ibu & $-4,842$ & $0,003^{*}$ & $-8,012-(-1,671)$ \\
Informasi & 5,920 & 0,047 & $0,082-11,758$ \\
Konstanta & & 0,192 & \\
$\mathrm{R}^{2}$ & & & \\
\hline
\end{tabular}




\begin{tabular}{llll}
\hline Model III & & & \\
Video & 5,347 & $0,001^{*}$ & $2,319-8,375$ \\
Informasi & $-4,891$ & $0,003^{*}$ & $-8,091-(-1,691)$ \\
Konstanta & 8,960 & $<0,001$ & $4,691-13,228$ \\
$\mathrm{R}^{2}$ & 0,176 & \\
\hline \multicolumn{2}{l}{ Keterangan: $\mathrm{n}:$ sampel; $p:$ signifikansi; dianalisis menggunakan uji regresi linier,$*): p<0,05 ; \mathrm{R}^{2}$}
\end{tabular}
video $=0,086$

Pada model ketiga skor video meningkatkan perilaku perawatan ibu 5,3 lebih tinggi dari pada kelompok kontrol. Sementara skor perilaku perawatan ibu pada responden yang belum pernah mendapatkan informasi meningkat 4,9 lebih tinggi dibandingkan responden yang telah mendapatkan informasi.

Nilai $\mathrm{R}^{2}$ pada model ketiga adalah 0,176 menunjukkan bahwa video dan informasi memberikan pengaruh terhadap perilaku perawatan ibu dengan balita pneumonia sebesar $17,6 \%$. Sementara nilai $\mathrm{R}^{2}$ pada video adalah 0,086 menunjukkan bahwa video memberikan pengaruh terhadap perilaku perawatan ibu dengan balita pneumonia sebesar $8,6 \%$.

\section{PEMBAHASAN}

Perilaku perawatan ibu dengan balita pneumonia setelah dilakukan intervensi mengalami peningkatan, baik pada kelompok perlakuan maupun pada kelompok kontrol. Intervensi yang dilakukan berupa edukasi kesehatan. Hal ini sejalan dengan penelitian Syahrani (2011) bahwa edukasi kesehatan dapat meningkatkan pengetahuan dan keterampilan ibu dalam melakukan perawatan balita dengan ISPA. Hasil penelitian Huriah (2008) juga menyatakan bahwa edukasi kesehatan memberikan pengaruh yang signifikan terhadap peningkatan pengetahuan, sikap, keterampilan, dan praktik ibu dalam melakukan perawatan balita dengan ISPA.

Hasil analisis data pada penelitian ini menunjukkan bahwa tidak ada perbedaan yang signifikan antara kelompok perlakuan dan kelompok kontrol sebelum dilakukan intervensi $(p>0,05)$. Sementara setelah dilakukan intervensi terdapat perbedaan yang signifikan antara kelompok perlakuan dan kelompok kontrol $(p<0,05)$. Hasil ini sejalan dengan penelitian Ani (2014) yang menunjukkan bahwa tidak ada perbedaan yang signifikan pada kelompok kontrol dan eksperimen pada saat pre test, sedangkan pada saat post test pada kelompok kontrol dan kelompok eksperimen terdapat perbedaan yang signifikan. Berdasarkan hasil tersebut dapat disimpulkan bahwa terdapat pengaruh edukasi terhadap perilaku perawatan ibu dengan balita pneumonia, sebagaimana Ani (2014) menyimpulkan bahwa terdapat pengaruh pemberian paket edukasi terhadap keterampilan ibu dalam perawatan balita dengan ISPA.

Pada kelompok kontrol tidak terdapat perbedaan antara post test I dengan post test II yang dilakukan setelah 21 hari pemberian intervensi $(p>0,05)$, sedangkan pada kelompok perlakuan terdapat perbedaan antara antara post test I dengan post test II yang dilakukan setelah 21 hari pemberian intervensi $(p<0,05)$. Hal ini dikarenakan kesadaran ibu dalam mengulangi kembali edukasi yang telah diberikan. Ibu pada kelompok perlakuan diberikan edukasi menggunakan video yang dikirimkan melalui aplikasi android, sehingga lebih intens membuka video yang diberikan karena ibu sering menggunakan gadget sehari-hari. Sementara ibu pada kelompok kontrol diberikan edukasi 
menggunakan leaflet, sehingga leaflet tersebut bisa robek ataupun hilang karena tidak setiap saat bersama ibu dan akhirnya ibu tidak dapat mengulangi kembali edukasi yang telah diberikan.

Hasil penelitian menunjukkan bahwa edukasi menggunakan video berpengaruh terhadap perilaku perawatan ibu dengan balita pneumonia. Ibu yang diberikan edukasi menggunakan video memiliki rerata perilaku yang lebih tinggi dari pada ibu yang diberikan edukasi menggunakan leaflet. Selain itu, ibu yang memperoleh edukasi menggunakan video mengalami peningkatan perilaku yang lebih tinggi dibandingkan ibu yang mendapatkan edukasi menggunakan leaflet. Sehingga dapat dikatakan bahwa media video lebih efektif dibandingkan leaflet terhadap perilaku perawatan ibu dengan balita pneumonia. Hal ini sejalan dengan penelitian Kasanah (2015) yang menunjukkan bahwa media video lebih berpengaruh dibandingkan media leaflet terhadap praktik perawatan kaki pasien diabetes mellitus.

Media video merupakan variabel yang mempengaruhi peningkatan perilaku perawatan ibu dengan balita pneumonia. Hal ini sejalan dengan penelitian Wea et al (2015) yang menyatakan bahwa pendidikan kesehatan dengan media video meningkatkan perilaku ibu dalam penanganan infeksi saluran pernafasan akut pada balita di kelurahan Lebijaga kabupaten Ngada. Namun hal ini bertentangan dengan hasil penelitian Abed et al. (2014) yang menunjukkan bahwa edukasi menggunakan video tidak mengalami peningkatan terhadap modifikasi perilaku pasien.

Hasil uji statistik menunjukkan bahwa dari keempat variabel luar yaitu usia, pendidikan, pendapatan, dan paparan informasi hanya ada 1 variabel yang berhubungan dengan perilaku perawatan ibu yaitu paparan informasi. Disimpulkan bahwa ada hubungan antara paparan informasi tentang perilaku perawatan pneumonia dengan perilaku ibu $(p<0,05)$.

Hasil analisis menunjukkan bahwa ada hubungan paparan informasi dengan perilaku perawatan ibu dengan balita pneumonia. Hal ini sejalan dengan penelitian Wahyuti (2012) yang menyatakan ada hubungan paparan informasi dengan pengetahuan pneumonia. Pengetahuan akan mempengaruhi perilaku perawatan ibu dengan balita pneumonia (Notoadmodjo, 2010). Apabila ibu dengan balita yang menderita pneumonia mematuhi cara merawat anaknya di rumah seperti cara pemberian obat kepada balita, pemberian makanan, tanda-tanda untuk segera kembali ke pelayanan kesehatan, serta cara menggunakan bahan yang aman untuk meredakan batuk di rumah, maka tingkat kesembuhan anak dapat dicapai dengan maksimal (Vitasari, 2011).

\section{KESIMPULAN}

Edukasi menggunakan video berpengaruh terhadap perilaku perawatan ibu dengan balita pneumonia di wilayah Piyungan Kecamatan Piyungan Kabupaten Bantul. Perilaku perawatan ibu sebelum diberikan edukasi pada kelompok perlakuan dalam kategori baik, dan perilaku perawatan ibu mengalami peningkatan setelah pemberian intervensi. Sama halnya dengan kelompok perlakuan, perilaku perawatan ibu sebelum diberikan edukasi kelompok kontrol dalam kategori baik, dan perilaku perawatan ibu mengalami peningkatan setelah pemberian intervensi. Paparan informasi merupakan variabel luar yang menunjukkan hubungan bermakna dengan peningkatan perilaku perawatan ibu. Bagi penelitian selanjutnya diharapkan dapat menganalisis hubungan faktor lingkungan seperti asap pembakaran sampah, keadaan lingkungan sekitar rumah, dan kepadatan hunian terhadap perilaku perawatan ibu dengan balita pneumonia. 


\section{REFERENSI}

Abed, M. A. (2014). Video-Assist Patient Education to Modify Behavior: A Systematic Review. Patient Education and Counseling 97(1):16-22. Doi: 10.1016/j.pec.2014.06.015.

Alfaqinisa, R. (2015). Hubungan antara tingkat pengetahuan, sikap, dan perilaku orang tua tentang pneumonia dengan tingkat kekambuhan pneumonia pada balita di wilayah kerja Puskesmas Ngesrep Kota Semarang tahun 2015. Skripsi, Universitas Negeri Semarang.

Ani, A. (2014). Pengaruh Pemberian Paket Edukasi Tentang MTBS ISPA Terhadap Tingkat Pengetahuan dan Keterampilan Ibu dalam Perawatan Balita dengan ISPA di Sentolo Yogyakarta. Naskah Publikasi, Universitas Muhammadiyah Yogyakarta.

Depkes RI. (2008). Profil Kesehatan Indonesia. Retrieved from http://www.depkes.go.id/resources/download/pusdatin/profil-kesehatanindonesia/profil-kesehatan-indonesia-2008.pdf

Huriah, T. (2008). Pengaruh Pendidikan Kesehatan Tentang Infeksi Saluran Pernafasan Akut (ISPA) terhadap Kemampuan Ibu dalam Perawatan ISPA pada Balita di Dusun Lemahdadi Kasihan Bantul Yogyakarta. Artikel Ilmiah, Universitas Muhammadiyah Yogyakarta.

Hockenberry, M.J. (2015). Wong's nursing care of infants and children $\left(9^{\text {th }}\right.$ ed.). United Stated of America: Elsevier.

Ismayani, Fine. (2017). Hubungan kualitas pelayanan kesehatan dengan perilaku ibu dalam penatalaksanaan diare pada balita di kecamatan Sentolo Kulon Progo D.I. Yogyakarta. Skripsi, Universitas Gadjah Mada.

Kasanah, A. (2015). Pengaruh media audio visual dan media pendukung leaflet terhadap praktik perawatan kaki pasien diabetes mellitus. Skripsi, Universitas Gadjah Mada.

Kementerian Kesehatan RI. (2017). Data dan informasi profil kesehatan Indonesia. Retrieved from http://www.pusdatin.kemkes.go.id/resources/download/pusdatin/profil-kesehatanindonesia/Data-dan-Informasi_Profil-Kesehatan-Indonesia-2017.pdf

Kemenkes RI. (2013). Riset Kesehatan Dasar. Retrieved from http://www.depkes.go.id/resources/download/general/Hasil\%20Riskesdas\%202013.p df

Maramis, P.A. (2013). Hubungan tingkat pendidikan dan pengetahuan ibu tentang ISPA dengan kemampuan ibu merawat balita ISPA pada balita di puskesmas Bahu kota Manado. Ejournal Keperawatan Volume 1 Nomor 1.

Notoadmodjo, S. (2011). Kesehatan Masyarakat: Ilmu dan Seni. Jakarta: Rineka Cipta.

Nurdin, L. (2015). Keefektifan ceramah dan Focus Group Discussion (FGD) terhadap tingkat pengetahuan dan sikap ibu tentang pneumonia balita. Skripsi, Universitas Gadjah Mada.

Sari, M.P. (2012). Gambaran pengetahuan ibu tentang perawatan pneumonia ringan pada balita di rumah di desa Sayang kecamatan Jatinangor. Skripsi, Universitas Padjadjaran.

Silalahi, V. (2017). Efektivitas pendidikan kesehatanmenggunakan media audiovisual dan booklet terhadap perilaku wanita dalam melakukan skrining inspeksi visual dengan asam asetat (IVA) untuk deteksi dini kanker serviks. Tesis, Universitas Gadjah Mada. 


\section{JINTAN : Jurnal Ilmu Keperawatan}

ISSN 2774-468X (Media Online)

Vol 1, No 2, Bulan Juli 2021

Hal 48-57

Syahrani, Santoso \& Suyono. (2011). Pengaruh Pendidikan Kesehatan Tentang Penatalaksanaan ISPA Terhadap Pengetahuan dan Keterampilan Ibu Merawat Balita ISPA di Rumah. Retrieved from http://180.250.144.147/ejournal/index.php/ilmukeperawatan/article/view/44/83.

Vitasari, A. (2011). Hubungan Kepatuhan Kunjungan Ulang dengan Membaiknya Pneumonia Pada Balita di Puskesmas Piyungan Bantul Yogyakarta. Naskah Publikasi, Sekolah Tinggi Ilmu Kesehatan 'Aisyiyah Yogyakarta.

Wahyuti. (2012). Hubungan Antara Pengetahuan Orangtua Tentang ISPA dengan Kejadian ISPA Pada Bayi di Wilayah Kerja Puskesmas Gatak Sukoharjo. Naskah Publikasi, Universitas Muhammadiyah Surakarta.

Wea, K.B., Kristiawati, Hidayati, L. (2015). Pendidikan kesehatan dengan media audiovisual meningkatkan perilaku ibu dalam penanganan infeksi saluran pernafasan akut pada balita di Kelurahan Lebijaga Kabupatan Ngada. Retrieved from journal.unair.ac.id/download-fullpapers-cmsnj413197a0dd2full.pdf 